\title{
EFFECT OF ARBUSCULAR MYCORRHIZA FUNGI INOCULATION ON TEAK (Tectona grandis Linn. F) AT CIKAMPEK, WEST JAVA
}

\author{
Ragil S.B. Irianto and Erdy Santoso ${ }^{1}$
}

\begin{abstract}
The aim of this study was to identify the effect of Arbuscular Mycorhiza Fungi (AMF) on the early growth of teak (Tectona grandis Linn. F) plantation. Teak seedlings were inoculated with Glomus aggregatum or Mycofer (mixing of four Arbuscular Mycorrhiza Fungi (AMF) : $G$. margarita, G. manihotis, G. etunicatum and Acalospora spinosa) at the time of transplantation. At three months old the seedlings were planted in Cikampek experimental forest. Results showed that application of G. aggregatum or mycofer to teak could accelerate height and diameter growth by up to $61 \%$ and $47 \%$, respectively, after three months in the field.
\end{abstract}

Keywords: teak, Tectonagrandis, AMF, Glomus, Acalospora, seedling

\section{INTRODUCTION}

Teak belongs to Verbenaceae which symbioses with Abuscular Mycorhiza Fungi (AMF). In Indonesia, more than 1 million hectares of lands planted with teak especially in Java Island and Lampung Province. Perum Perhutani ${ }^{2}$ alone has a total of teak plantation of 1,423,676 hectares mostly in East and Central Java producing teak logs of about $800,000 \mathrm{~m}^{3} /$ year. Due to the high economic value of teak, currently many farmers in Java, Sumatra and Kalimantan are in high wood of planting teak with seedlings from seed or tissue culture production. Perum Perhutani and farmers need millions seedlings to replace teak plantation harvested every year. Teak is commonly planted on land with low soil fertility, therefore it need fertilizer and beneficial symbiont such as AMF.

Application of AMF (Glamus agregatum and Mycofer R.) on T. Grandis seedlings could accelerate the growth of height and diameter (Asmanah, 2000). The symbiotic of AMF with higher plants plays an important role in plant nutrition cycle (Harley and Smith, 1983). The AMF stimulates the growth of many tropical trees and shrubs by enhancing the uptake of nutrient elements such as phosphorus, nitrogen, potassium and by increasing the resistance of plants to drought stress and root pathogens (Janos, 1988; Michelsen and Rosendahl, 1990). The aim of this study was to determine the effect of AMF inoculation on the growth of young teak plantation in the field.

\footnotetext{
${ }^{1}$ Forest and Nature Conservation Research and Development Center, Bogor

${ }^{2}$ Perum Perhutani is a state-owned company holding a mandate for managing production in Java, which is mainly teak plantation
} 


\section{METHOD}

\section{A. Location}

This research was conducted in Cikampek Experimental Forest Purwakarta District West Java. This site has an annual rainfall of $1891 \mathrm{~mm}$. The soil type is an association of red latosol and reddish brown latosol.

\section{B. Treatment}

Three seedlots of T. grandis namely seedlot 52, 58 and 63 were obtained from The Centre for Forest Resources Development, Perum Perhutani, Cepu Central Java. Soil media were yellowish red podzolic from dipterocarp plantation. Two kinds of AMF : Glomus aggregatum (produced by Osaka Gas) and Mycofer (consisting of 4 species AMF i.e. $G$. margarita, G. manibotis, $G$. etunicatum and $A$. spinosa) were inoculated individually. The innoculated teak seedlings were planted in Cikampek Experimental Forest in West Java using $3 \times 4 \mathrm{~m}$ and $30 \times 30 \times 30 \mathrm{~cm}$ planting holes on December 1999 .

\section{Data Analysis}

Parameters observed from plant growth study in the field consisted of height and diameter of three-month-old of T. grandis ( 3 months after planting). Data were analysed with Duncan's multiple range test using SAS 6.12 software.

\section{RESULTS AND DISCUSSION}

Results of height and diameter of T. grandis inoculated with AMF in 3 seedlots are listed in Table 1.

Table 1. Effect of Arbuscular Mycorrhiza Fungi on T. grandis (Seedlot 52, 63 and 58) growth in the field.

\begin{tabular}{|c|l|r|r|r|}
\hline \multirow{2}{*}{ Seedlot } & \multirow{2}{*}{ Parameter } & \multicolumn{3}{|c|}{ Mycorrhiza } \\
\cline { 3 - 5 } & & G.aggregatum & \multicolumn{1}{|c|}{ Mycofer } & \multicolumn{1}{|c|}{ Control } \\
\hline \multirow{2}{*}{52} & Height $(\mathrm{cm})$ & $48.06 \mathrm{a}(61.38)$ & $40.73 \mathrm{~b}(36.77)$ & $29.78 \mathrm{c}(0.00)$ \\
& Diameter $(\mathrm{mm})$ & $10.99 \mathrm{a}(14.96)$ & $8.99 \mathrm{~b}(5.96)$ & $9.56 \mathrm{~b}(0.00)$ \\
\hline \multirow{2}{*}{63} & Height $(\mathrm{cm})$ & $38.50 \mathrm{a}(60.62)$ & $35.51 \mathrm{a}(48.14)$ & $23.97 \mathrm{~b}(0.00)$ \\
& Diameter $(\mathrm{mm})$ & $8.39 \mathrm{a}(20.89)$ & $8.09 \mathrm{a}(16.57)$ & $6.94 \mathrm{a}(0.00)$ \\
\hline \multirow{2}{*}{58} & Height $(\mathrm{cm})$ & $31.48 \mathrm{ab}(16.51)$ & $38.34 \mathrm{a}(41.89)$ & $27.02 \mathrm{a}(0.00)$ \\
& Diameter $(\mathrm{mm})$ & $8.95 \mathrm{~b}(16.54)$ & $11.28 \mathrm{a}(46.88)$ & $7.68 \mathrm{~b}(0.00)$ \\
\hline
\end{tabular}

Notes:

1. Means followed by the same letters are not significantly different at $\mathrm{p}=0.05$ according to Duncan's multiple range test.

2. Numeric in the parantheses denote percentage increase over control 
Application of $G$. aggregatum resulted in a higher effect on seedlot 52 and 63 with the acceleration of height was $16 \%$. Meanwhile, plants infected by mycofer on seedlot 58 showed a higher growth than those on seedlot 52 and 63. According to Triwahyuni (2000) inoculation of mycofer provides a higher result than that of G. aggregatum in terms of height of seedlings. On the other hand, Chavez and Ferrera-Cerato (1990) reported that AMF effects differ widely with host-endophyte combinations in micro propagated strawberry. This might be due to the existence of some physiological host preference/specificity in these fungi. According to Suhendi (2005, pers. comm.), the difference of growth on three seedlots could also be caused by genetic variation.

In general as shown in Table 1, mycorrhiza has a great influence in increasing the height and diameter (plant growth) compared to non-mycorrhizal plant. The majority of soils in tropical ecosystem are known to be deficient of available $\mathrm{P}$ and $\mathrm{N}$, both of which are important nutrients for growth (Kang and Wilson, 1987). Harley and Smith (1983) reported that $\mathrm{AMF}$ has a significant effect in improving plant growth when little phosphate is present in the soil. Roo-external AMF mycelium grows well and increases the soil volume which is exploited for $\mathrm{P}$ uptake. Higher concentration of potassium $(\mathrm{K})$ and nitrogen $(\mathrm{N})$ are found in mycorrhizal than non-mycorrhizal plants (Sieverding, 1991; Irianto and Utami, 2001). Micronutrients such as Zinc $(\mathrm{Zn})$, copper $(\mathrm{Cu})$, sulphur (S), boron (B), molybdenum (Mo), iron $(\mathrm{Fe})$, manganese $(\mathrm{Mn})$ and chlorine $(\mathrm{Cl})$ are generally found in higher concentration in mycorrhizal than non-mycorrhizal plants (Sieverding, 1991). Furthermore, Druge and Schonbek (1992) reported that AMF symbiosis could raise internal cytokinin levels and this is as a main factor causing improvement of plant growth.

Table 2. Effect of Arbuscular Mycorrhiza Fungi on T. grandis (seedlot 63) growth in the field

\begin{tabular}{|c|c|c|}
\hline Kinds of Mycorrhizas & $\begin{array}{c}\text { Height } \\
(\mathrm{cm})\end{array}$ & $\begin{array}{c}\text { Diameter } \\
(\mathrm{mm})\end{array}$ \\
\hline G. aggregatum & $38.50 \mathrm{a}$ & $8.39 \mathrm{a}$ \\
& $(60.62)$ & $(20.89)$ \\
\hline Mycofer & $35.51 \mathrm{a}$ & $8.09 \mathrm{a}$ \\
& $(48.14)$ & $6.94 \mathrm{a}$ \\
\hline Control & $23.97 \mathrm{~b}$ & $(0.00)$ \\
\hline
\end{tabular}

Notes:

1. Means followed by the same letters are not significantly different at $\mathrm{p}=0.05$ according to Duncan's multiple range test.

2. Numeric in the parantheses denote percentage increase over control

Table 3. Effect of Arbuscular Mycorrhiza Fungi on T. grandis (seedlot 58) growth in the field

\begin{tabular}{|c|c|c|}
\hline Kinds of Mycorrhizas & $\begin{array}{c}\text { Height } \\
(\mathrm{cm})\end{array}$ & $\begin{array}{c}\text { Diameter } \\
(\mathrm{mm})\end{array}$ \\
\hline G. aggregatum & $31.48 \mathrm{ab}$ & $8.95 \mathrm{~b}$ \\
& $(16.51)$ & $(16.54)$ \\
\hline Mycofer & $38.34 \mathrm{a}$ & $11.28 \mathrm{a}$ \\
& $(41.89)$ & $(46.88)$ \\
\hline Control & $27.02 \mathrm{a}$ & $768 \mathrm{~b}$ \\
& $(0.00)$ & $(0.00)$ \\
\hline
\end{tabular}

Notes:

1. Means followed by, the same letters are not significantly different at $\mathrm{p}=0.05$ according to Duncan's multiple range test.

2. Numeric in the parantheses denote percentage increase over control 
Inoculation of $G$. aggregatum to seedlot 52 could accelerate the height and diameter of young plant by $61.38 \%$ and $14.96 \%$ and seedlot 63 by $60.62 \%$ and $20.89 \%$, respectively, compared to control. While inoculation of mycofer to seedlot 52 could accelerate the growth of height and diameter by $36.77 \%$ and $5.96 \%$ and seedlot 63 by $48.14 \%$ and $16.57 \%$, respectively, compared to control (Table 1 and 2). Moreover, inoculation of mycofer to seedlot 58 could accelerate greater than $G$. agregatum to the height and diameter of threemonth-old young plant in the field (Table 3 ).

Plants infected by $G$. aggregatum showed higher result on seedlot 52 and 63 with the acceleration of height more than $60 \%$, but for seedlot 58 the acceleration of height was $16 \%$. Meanwhile, plants infected by mycofer showed higher result on seedlot 58 than seedlot 52 and 63. These results were similar to the results reported by Triwahyuni (2000); inoculation of mycofer to seedlot 3 and 7 provided the higher result than $G$. aggregatum to height of seedlings. Chavez and Ferrera-Cerrato (1990) reported that AMF effects differ widely with hostendophyte combinations in micro propagated strawberry. This might be due to the existence of some physiological host preference/specificity in these fungi.

Mycorrhizal plants have a great influence in increasing the height and diameter (plant growth) compared to non-mycorrhizal plant (Tables 1, 2 and 3). The majority of soils in tropical ecosystem are known to be deficient in available $\mathrm{P}$ and $\mathrm{N}$, both of which are important nutrients for growth (Kang and Wilson, 1987). Harley and Smith (1983) reported that $\mathrm{AMF}$ has their significant effect in improving plant growth when little phosphate is present in the soil. Root-external AMF mycelium grows well and increases the soil volume where is exploited for P uptake. Higher concentration of potassium $(K)$ and nitrogen $(N)$ are found in mycorrhizal than non-mycorrhizal plants (Sieverding, 1991; Irianto and Utami, 2001). Micronutrients such as Zinc ( $\mathrm{Zn})$, copper $(\mathrm{Cu})$, sulphur (S), boron (B), molybdenum (Mo), iron (Fe), manganese $(\mathrm{Mn})$ and chlorine $(\mathrm{Cl})$ are generally found in higher concentration in mycorrhizal than non-mycorrhizal plants (Sieverding, 1991).

Furthermore, Drüge and Schönbeck (1992) reported that AMF symbiosis could raise internal cytokinin levels and this is as main factor causing improvement of plant growth.

\section{CONCLUSION}

Seedlings inoculated with $G$. aggregatum or mycofer could accelerate height and diameter growth of young plant by up to $61 \%$ and $47 \%$, respectively, after three months in the field. Application of AMF at nursery may be used to increase growth of seedlings in the nursery and plants in the field, hence reducing the use of synthetic fertilization.

\section{ACKNOWLEDGEMENT}

This research was funded by Osaka Gas Co. Ltd. Japan. We thank to Mr. Sugeng Santosa and Mr. Najmullah for their help in the field. 


\section{REFERENCES}

Asmanah, N. 2000. Effect of Arbuscular Mycorrhiza Fungi on Tectona grandis L.f. in Nursery. Bachelor Thesis, Department of Biology Universitas Pakuan, Bogor.

Chavez, M.G. and R. Ferrera-Cerato. 1990. Effect of vesicular-arbuscular mycorrhiza on tissue culture-derived plants of strawberry. Hort. Sci. 25:903-905.

Drüge, U and F. Schönbeck. 1992. Effect of vesicular-arbuscular mycorrhizal infection on transpiration, photosynthesis and growth of flax (Linum usitatissiumum L.) in relation to cytokinin levels. J. Plant Physiol. 141: 40-48.

Harley, J.L. and S.E. Smith. 1983. Mycorrhizal Symbiosis. Academic Press, New York.

Irianto, R.S.B and S. Utami. 2001. Effect of arbuscular mycorrhiza fungi on Paraserianthes falcataria seedlings. A Research Report, Unpublished.

Janos, D.P. 1988. Mycorrhiza applications in tropical forestry: are temperate-zone approaches appropriate? In Ng F.S.P. (Editor), Trees and Mycorrhiza. Forest Research Institute, Kuala Lumpur, Malaysia, pp. 133-188.

Kang, B.T. and G.F. Wilson. 1987. The development of alley cropping as a promising agro forestry technology. In Steppler H.A. and P.K.R. Nair (Eds.) Agro forestry: A Decade of Development, pp 227-243. ICRAF, Nairobi, Kenya.

Michelsen, A. and S. Rosendahl. 1990. The effect of VA Mycorrhizal fungi, phosphorus and drought stress on the growth of Acacia nilotica and Leucaena leucocephala seedlings. Plan Soil 124: 7-13.

Schmidt, F.H. and J.H. Ferguson. 1951. Rainfall type based on wet and dry period ratios for Indonesia with Western New Guinea. Jawatan Meteorologi dan Geofisika, Verh No. 42, Jakarta.

Sieverding, E. 1991. Vesicular-Arbuscular Mycorrhiza Management in Tropical Agro system. GTZ GmbH.

Triwahyuni, C. 2000. Effectiveness of some arbuscular mycorrhiza fungi on teak (Tectona grandis Linn F). In Using Mycorrhiza as Friendly Biotechnological Agent in Increasing Land Productivity on Forestry, Agriculture and Estate in New Millennia Era. National Conference Mycorrhiza I, Bogor 15-16 November 1999. 